\title{
Mesencephalic Dopaminergic Neurons in Primary Cultures Express Functional Neurotensin Receptors
}

\author{
Aline Brouard, Didier Pelaprat, Corinne Dana, Micheline Vial, Anne-Marie Lhiaubet, and William Rostène \\ Institut National de la Santé et de la Recherche Médicale, Unité 339, Hôpital Saint Antoine, 75012 Paris, France
}

\begin{abstract}
The cellular distribution and functional aspects of neurotensin (NT) binding sites in rat mesencephalic cells in primary culture were investigated by an original approach combining anatomical and biochemical studies. Using a double-labeling protocol combining ${ }^{225}$ I-NT receptor radioautography and tyrosine hydroxylase (TH) immunocytochemistry, we obtained the first direct visualization of NT binding sites on TH-immunoreactive neurons. Eighty percent of the TH neurons were endowed with NT binding sites, which can be observed on both cell bodies and processes. TH-immunoreactive neurons were characterized as dopaminergic neurons by their ability to take up dopamine in a benztropine- and nomifensine-sensitive manner. In the mesencephalic cultures, NT increased potassium-evoked release of tritiated dopamine, and the relative potencies of various NT-related peptides to increase dopamine release were in good agreement with their abilities to bind to NT sites. These results show for the first time that cultured rat mesencephalic dopaminergic cells express functional NT receptors. Finally, the specificity and distribution of NT receptors on dopaminergic neurons in primary culture are quite similar to what was observed in the adult rat brain using pharmacological and radioautographic approaches. These data indicate that NT can influence the activity of dopaminergic neurons at very early stages of the rat brain development.
\end{abstract}

Mesencephalic dopaminergic (DAergic) neurons have raised a considerable interest during the past 30 years, and dysfunctions of these neurons have been demonstrated or suspected in pathological states such as Parkinson's discase (Ehringer and Hornykiewicz, 1960) or schizophrenia (Matthysse and Kety, 1975). A better knowledge of the various factors regulating DAergic transmission and the anatomical bases of these regulations might lead to new therapeutic approaches for the treatment of these diseases.

An increasing body of evidence supports the notion that neurotensin (NT), a tridecapeptide originally isolated from bovine hypothalamus (Carraway and Leeman, 1973), could modulate the activity of mesencephalic DAergic neurons by acting on DA cell bodies or terminals. For instance, NT enhances the firing

Received June 26, 1991; revised Oct. 25, 1991; accepted Nov. 18, 1991.

We thank A. Le Nédic, V. Raphael, and S. Millcrioux for their skillful technical assistance, and Y. Issoulie for photographs. This work was supported by the Association pour la Recherche contre le Cancer (fellowship to C. Dana) and the Ministere de la Recherche et de la Technologie (fellowship to A. Brouard).

Correspondence should be addressed to Dr. William Rostène, Institut National de la Santé et de la Recherche Médicale, Unité 339, Hôpital Saint Antoine, 184 rue du faubourg Saint Antoine, 75012 Paris, France.

Copyright (C) 1992 Society for Neuroscience $0270-6474 / 92 / 121409-07 \$ 05.00 / 0$ of DAergic neurons (Pinnock, 1985; Seutin et al., 1989) and facilitates DA release (De Quidt and Emson, 1983; Hetier et al., 1988; Blaha et al., 1990), and injection of the peptide in the ventral tegmental area (VTA) induces an increase in locomotion (Kalivas et al., 1983; Cador et al., 1985) and hypothermia (Kalivas, 1985). Moreover, recent anatomical data demonstrate that NT-immunoreactive fibers and terminals surrounding tyrosine hydroxylase (TH)-immunoreactive (TH-IR) perikarya and processes can be observed in rat VTA and substantia nigra (SN; Hökfelt et al., 1984; Woulfe and Beaudet, 1989).

The effects of NT on DAergic neurons suggest that these neurons possess NT receptors. This hypothesis has been indirectly supported by results of lesion studies showing that in the rat mesencephalon, densities of NT binding sites were greatly diminished after destruction of DAergic neurons with 6-hydroxydopamine (Palacios and Kuhar, 1981; Quirion et al., 1985; Hervé et al., 1986), and by a recent approach, using NT receptor radioautography and $\mathrm{TH}$ immunocytochemistry on adjacent brain sections (Szigethy and Beaudet, 1989). This association of NT binding sites with DA neurons seems also to occur in man, since decreases in nigral and striatal NT binding site densities have been reported in Parkinson's disease (Sadoul et al., 1984; Uhl et al., 1984; Rostène et al., 1988; Chinaglia et al., 1990).

In the aforementioned studies, the modulatory action of NT on DAergic neurons was investigated on adult brain, mainly in the rat. However, the presence of NT binding sites in the rat mesencephalon was detected very early during ontogeny ( $\mathrm{Pa}$ lacios et al., 1988), as measurable amounts of NT sites could be observed in this region at prenatal day 18 . The functional aspect of these sites, and particularly the existence of an effect of NT on DAergic neurons at an early developmental stage, is not known. Moreover, no evidence is available as to whether NT sites detected in the mesencephalon in the perinatal period are localized on DA neurons or on other types of cells.

In order to study those different aspects, we thus decided to use primary cultures of dissociated brain cells. Indeed, numerous studies had shown that primary cultures of rat or mouse embryonic mesencephalic cells contained DAergic neurons that develop morphological and biochemical characteristics similar to those found in vivo (Berger et al., 1982; Barbin et al., 1985; Dal Toso et al., 1988; Engele et al., 1989). Furthermore, the presence of high-affinity NT binding sites was detected in primary cultures of embryonic mouse whole brain cells (Checler et al., 1986) and mouse mesencephalic cells (Chabry et al., 1990), and recently NT sites were also found in rat mesencephalic cells (Dana et al., 1991). Since primary cultures of embryonic brain cells have been used over the last 10 years to investigate various functional aspects of neurotransmission (Bockaert et al., 1986; Thomas, 1986), we hypothesized that such cultures might pro- 
vide suitable models to study the cellular localization of brain NT binding sites and its functional consequences.

In the present work, we use an original double-labeling protocol combining ${ }^{125}$ I-NT high-resolution radioautography and TH immunocytochemistry to visualize directly the presence of NT binding sites on cultured rat mesencephalic DAergic neurons. Moreover, we show that these binding sites are functional NT receptors involved in the regulation of DA release.

\section{Materials and Methods}

Embryonic rat brain dissection and cell culture conditions. Mesencephalic cells in culture were prepared from embryonic day 15 Wistar rats, as previously described (Berger et al., 1982), with several modifications. Mesencephalic tegmentum was dissected in phosphate-buffered saline (PBS: $\mathrm{NaCl}, 137 \mathrm{~mm} ; \mathrm{Na}_{2} \mathrm{HPO}_{4}, 21 \mathrm{~mm} ; \mathrm{KH}_{2} \mathrm{PO}_{4}, 29 \mathrm{~mm} ; \mathrm{KCl}$, $1.2 \mathrm{~mm} ; \mathrm{pH} 7.3$ ). Cells were mechanically dissociated in serum-free medium (SFM) consisting of a mixture of Dulbecco's modified essential medium and Ham-F12 (1:1, v/v, both from GIBCO), supplemented with $14 \mathrm{~mm}$. glucose, $15 \mathrm{~mm} \mathrm{NaHCO}, 5 \mathrm{~mm}$ HEPES, $0.05 \mathrm{~J} / \mathrm{ml}$ of penicillin, and $20 \mu \mathrm{g} / \mathrm{ml}$ of streptomycin (Seromed). Cells were then collected by centrifugation $(500 \times \mathrm{g}, 5 \mathrm{~min})$, resuspended in SFM complemented with $10 \%$ fetal calf serum (Boehringer) at a concentration of 1 million cells $/ \mathrm{ml}$, and plated at a density of 0.5 million cells per well, in 24 well Costar multiwell plastic culture plates previously coated with gelatin $(250 \mu \mathrm{g} / \mathrm{ml}, 30 \mathrm{~min}$, room temperature) and polyornithine (MW $=40,000,1.5 \mu \mathrm{g} / \mathrm{ml}$, overnight at room temperature). For radioautography and immunocytochemistry, cells were grown on glass slides added in the wells just before the coating procedure. For ${ }^{3} \mathrm{H}$-DA release experiments, the cells were plated at a density of 1 million cells per well. The cultures were incubated at $37^{\circ} \mathrm{C}$ in a water-saturated $95 \%$ air, $5 \%$ $\mathrm{CO}_{2}$ atmosphere. Medium was totally removed at day 5 and replaced by fresh medium containing cytosine arabinoside (AraC; $20 \mu \mathrm{M}$ ) to limit the proliferation of glial cells (Greene and Rein, 1976). Half of the medium was then replaced every day from day 6 by medium without AraC, and cells were used after $9 \mathrm{~d}$ in culture.

Binding procedurcs. Cells were incubated $60 \mathrm{~min}$ at $37^{\circ} \mathrm{C}$ with $0.3 \mathrm{~nm}$ ${ }^{125} \mathrm{I}-\mathrm{Tyy}^{3}-\mathrm{NT}$ [ ${ }^{125} \mathrm{I}-\mathrm{NT}, 2000 \mathrm{Ci} / \mathrm{mmol}$, prepared as previously described by Sadoul et al. (1984)] in SFM supplemented with $0.2 \%$ BSA and containing $0.3 \mathrm{~mm}$ phenylmethylsulfonyl fluoride and $1 \mathrm{~mm} O$-phenanthroline to prevent degradation of the ligand (Checler et al., 1986). Nonspecific binding, determined in the presence of $1 \mu \mathrm{M}$ unlabeled NT, routinely represented less than $15 \%$ of the total binding. At the end of the incubation, the cells were rapidly washed twice with cold SFM/BSA. Cells were scraped off in $0.1 \mathrm{~N} \mathrm{NaOH}$, and radioactivity was estimated with an LKB gamma counter. Competition experiments were performed by incubating ${ }^{125} \mathrm{I}-\mathrm{NT}(0.3 \mathrm{nM})$ in the presence of increasing amounts of unlabeled NT or related analogs. NT, Acetyl- $\mathrm{NT}_{8-13}\left(\mathrm{AcNT}_{8-13}\right)$, and neuromedin $\mathrm{N}$ were from Neosystem Laboratories (Strasbourg, France). $\mathrm{NT}_{1-11}$ was donated by Dr. P. Kitabgi (Centre CNRS, Nice, France), and levocabastine was a gift of Dr. A. Schotte (Janssen Pharmaceutica, Beerse, Belgium).

The maximal number of binding sites $\left(B_{\max }\right)$ and the dissociation constant $\left(K_{d}\right)$ for ${ }^{125}$ I-NT were determined from the least-squares linear regression of Scatchard $\left(B / F=B_{\max } / K_{d}-\left(1 / K_{d}\right) B\right)$ analysis of saturation isotherms. The inhibitory constant $\left(K_{i}\right)$ of the various nonradioactive compounds was calculated from the equation $K_{i}=\mathrm{IC}_{50} /\left(1+L / K_{d}\right)$ (Cheng and Prusoff, 1973), where $\mathrm{IC}_{50}$ was the concentration of the inhibitor that decreased binding of the radioligand by $50 \%, L$ the concentration of the labeled ligand, and $K_{d}$ the dissociation constant.

Radioautography. Incubation step with ${ }^{125}$ I-NT and washes were performed as described above. The cells were then fixed with 3.5\% glutaraldehyde in 0.1 m sodium phosphate buffer ( $\mathrm{pH} \mathrm{7.4)}$ for $30 \mathrm{~min}$ (Dana et al., 1989). On the mesencephalic cultures, this procedure led to covalent cross-linking of $50 \%$ of bound ${ }^{125}$ I-NT to, or nearby, its binding site. Cells were then dehydrated in graded ethanol/water baths $(70: 30$, $2 \times 5 \mathrm{~min} ; 90: 10,2 \times 5 \mathrm{~min} ; 100: 0,2 \times 10 \mathrm{~min}$ ) at room temperature to remove unfixed ligand. The slides were dipped in Ilford $\mathrm{K}_{\text {, nuclear }}$ emulsion diluted $1: 1$, and exposed for 3 weeks at $4^{\circ} \mathrm{C}$. The radioautographs were developed in D19 (Kodak, $3 \mathrm{~min}$ at $18^{\circ} \mathrm{C}$ ). Cells were stained with cresyl violet, examined, and counted under a Leitz Dialux microscope coupled to an image analyzer RAG 200 (Biocom, Les Ulis, France).

Tyrosine hydroxylase (TH) immunocytochemistry. Cultures were fixed for $30 \mathrm{~min}$ with $4 \%$ paraformaldehyde and $0.08 \%$ glutaraldehyde in
Sorensen buffer $(0.1 \mathrm{~m}$ sodium phosphate buffer, $\mathrm{pH} 7.4$, used for all dilutions except when indicated). Following three washes with $0.1 \mathrm{M}$ lysine, cells were preincubated $30 \mathrm{~min}$ with $0.05 \%$ saponin and $3 \%$ normal goat serum (NGS), incubated overnight at $4^{\circ} \mathrm{C}$ with anti-TH antibody [1:5000 dilution, Institut J. Boy, Reims, France (Arluison et al., 1984)], in $1 \% \mathrm{NGS}$, and incubated for $30 \mathrm{~min}$ with biotinylated antibody anti-rabbit IgG (Kit Vectastain, Vector laboratories) and then for $45 \mathrm{~min}$ with avidin-biotin peroxidase complex, with three $20 \mathrm{~min}$ rinses in $1 \%$ NGS between each step. Cells were finally incubated for $10 \mathrm{~min}$ with $0.1 \mathrm{M}$ Tris- $\mathrm{HCl}$ buffer $\mathrm{pH} 7.4$ containing $0.25 \%$ diaminobenzidine (DAB) and $0.01 \% \mathrm{H}_{2} \mathrm{O}_{2}$, rinsed with Sorensen, dehydrated in a graded series of ethanol, and mounted in DPX (Fluka).

Double-labeling experiments. After the ${ }^{125} \mathrm{I}-\mathrm{NT}$ binding procedure (incubation step and rinses), cells were fixed in 1\% glutaraldehyde and dehydrated as for radioautography. TH immunocytochemistry was then performed as described above. After visualization of the DAB staining, glass slides bearing the cells were removed from the wells and dipped in Ilford $K_{s}$ emulsion, and the radioautographic protocol was used as before.

Release of tritiated dopamine $\left({ }^{3} \mathrm{H}-\mathrm{DA}\right) .{ }^{3} \mathrm{H}-\mathrm{DA}$ release experiments were performed as described by Mount et al. (1989). Briefly, the cells were incubated for $20 \mathrm{~min}$ at $37^{\circ} \mathrm{C}$ with $50 \mathrm{~nm}{ }^{3} \mathrm{H}$-DA (New England Nuclear, $37 \mathrm{Ci} / \mathrm{mmol}$ ), and release experiments were subsequently performed at $20^{\circ} \mathrm{C}$. A basal release fraction of $5 \mathrm{~min}$ was first recovered, followed by a $5 \mathrm{~min}$ high potassium fraction $(20 \mathrm{~mm} \mathrm{KCl})$ in the presence or absence of NT analogs. During these two periods, $o$-phenanthroline $(0.1 \mathrm{~mm})$ was added in the medium to prevent peptide degradation (Checler et al., 1986). At the end of the experiment, residual intracellular radioactivity was extracted from the cells by adding $0.5 \mathrm{ml}$ of $\mathrm{NaOH}$ $0.1 \mathrm{~N}$ in the wells, and ${ }^{3} \mathrm{H}-\mathrm{DA}$ release in the basal and evoked fractions was expressed as a percentage of the total intracellular ${ }^{3} \mathrm{H}-\mathrm{DA}$ content at the beginning of the corresponding release period.

\section{Results}

Characterization and visualization of high-affinity NT binding sites in mesencephalic cultures

As shown in Figure 1, an apparent single class of high-affinity ${ }^{125} \mathrm{I}-\mathrm{NT}$ binding sites was detected in rat mesencephalic cells grown for $9 \mathrm{~d}$ in primary culture (Fig. 1A). The apparent dissociation constant $\left(K_{d}\right)$ was $0.30 \pm 0.04 \mathrm{nM}(n=6)$, and the maximal number of sites $\left(B_{\max }\right)$ was $2.84 \pm 0.30 \mathrm{fmol} /$ well ( $n$ $=6$ ). NT, $\mathrm{AcNT}_{8-13}$, and neuromedin $\mathrm{N}$ were potent competitors of ${ }^{125}{ }^{2}-N T$ binding, while $\mathrm{NT}_{1-11}$ and levocabastine were inactive (Fig. 1B).

Radioautograms taken from cells incubated with ${ }^{125} \mathrm{I}-\mathrm{NT}$ showed that some individual cells were labeled (Fig. $2 A, B$ ). Silver grains were found on both cell bodies and their proximal processes. The number of cells labeled by ${ }^{125} \mathrm{I}-\mathrm{NT}$ was $687 \pm$ 30 cells/well $(n=8)$, which represented $0.14 \%$ of the initial number of cells. Such a cellular accumulation of grains was not observed on cells incubated with the radioligand in the presence of $1 \mu \mathrm{M}$ unlabeled NT, where only scarce silver grains were found (nonspecific binding; Fig. 2C).

\section{Characterization and visualization of DAergic neurons}

In a second series of experiments, TH immunocytochemistry revealed the presence, in the mesencephalic cultures, of TH-IR cells (Fig. 3). These cells were bi- or multipolar, with various perikaryal shapes, and endowed with long processes bearing varicosities (Fig. $3 \mathrm{~A}-\mathrm{C}$ ). The number of TH-IR cells was 407 \pm 13 cells/well $(n=8)$. The neurochemical identity of these TH-IR cells was further investigated in ${ }^{3} \mathrm{H}$-DA uptake experiments. Double-labeling experiments confirmed that TH-IR cells were able to take up ${ }^{3} \mathrm{H}$-DA (data not shown). As illustrated in Figure 4 , the DA uptake inhibitors benztropine $(5 \mu \mathrm{M})$ and nomifensine $(5 \mu \mathrm{M})$ dramatically reduced ${ }^{3} \mathrm{H}-\mathrm{DA}$ uptake levels to $5 \%$ (4.92 $\pm 0.49 \%, n=4$, and $4.26 \pm 0.47 \%, n=4$, respectively) 

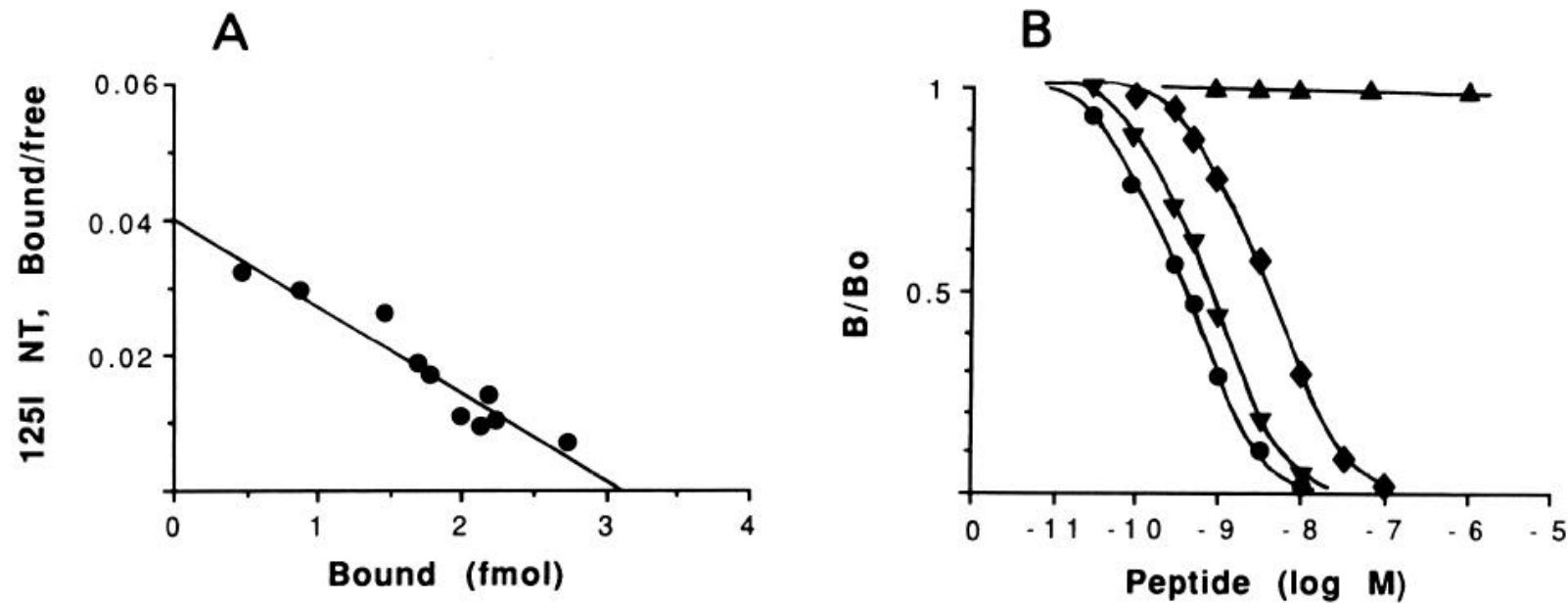

Figure 1. Specific binding of ${ }^{125}$ I-NT to rat mesencephalic cells in culture. A, Scatchard plot of saturation data of one representative experiment. Cells were incubated as described in Materials and Methods with increasing concentrations (0.05-1.5 nM) of ${ }^{125} \mathrm{I}-\mathrm{NT}$. Specific binding was calculated as the difference between binding in the absence (total binding) and in the presence (nonspecific binding) of $1 \mu \mathrm{M}$ unlabeled NT. $B$, Competition data. Each curve illustrates one representative experiment performed with the corresponding competitor. Cells were incubated with 0.3 nM ${ }^{125} \mathrm{I}-$ NT in the presence of increasing concentrations of competitors. Specific binding was defined as described in $A$. $B_{0}$ and $B$, Binding in the absence and in the presence of competitor, respectively. $\bullet, \mathrm{AcNT}_{8-13} ; \boldsymbol{\nabla}, \mathrm{NT} ;$, neuromedin $\mathrm{N} ; \boldsymbol{\Delta}, \mathrm{NT}_{1-10}, \mathrm{NT}_{1-11}$, levocabastine. Each point was the mean of four determinations, and the experiments were done three times. $M$, competitor concentration.

of the control values, while $84 \%(84.01 \pm 4.28 \%, n=4)$ of the ${ }^{3} \mathrm{H}$-DA uptake was still observed in the presence of the noradrenaline uptake inhibitor desipramine $(5 \mu \mathrm{M})$. Similarly, $86 \%$ of the ${ }^{3} \mathrm{H}-\mathrm{DA}$ uptake remained in the presence of the 5-HT uptake inhibitor fluoxetine ( $1 \mu \mathrm{M}$, data not shown). These data demonstrated that the majority of TH-IR cells in these cultures represented DA neurons.

\section{Combined ${ }^{125} \mathrm{I}-\mathrm{NT}$ radioautography and $\mathrm{TH}$ immunocytochemistry}

The relationship between ${ }^{125} \mathrm{I}-\mathrm{NT}$-labeled cells and DAergic neurons was then investigated in double-labeling experiments combining ${ }^{125}$ I-NT radioautography and TH immunocytochemistry. Unfortunately, we observed that the high aldehyde concentration ( $3.5 \%$ glutaraldehyde) previously used in radioautography to cross-link ${ }^{125}$ I-NT destroyed the immunocytochemical signal for TH. It was therefore necessary to find compatible fixation conditions. Decreasing the glutaraldehyde concentration from $3.5 \%$ to $1 \%$ significantly decreased neither the amount of cross-linked ${ }^{125} \mathrm{I}-\mathrm{NT}(50.1 \pm 1.3 \%, n=6$, and $47.5 \pm 1.7 \%, n=6$, respectively), nor the number of ${ }^{125}$ I-NTlabeled cells ( $682 \pm 45$ vs. $711 \pm 62$ cells/well, $n=6$ ). Similarly, the number of TH-IR cells was not modified when $4 \%$ paraformaldehyde, $0.08 \%$ glutaraldehyde was replaced by $1 \%$ glutaraldehyde alone $(430 \pm 26, n=6$, and $417 \pm 34$ cells/well, $n=6$, respectively) in the immunocytochemical procedure. Thus, $1 \%$ glutaraldehyde was used in the double-labeling protocol to cross-link ${ }^{125}$ I-NT to its binding sites.

The results of the double-labeling experiments are presented in Figure 5 and Table 1. Using this approach, ${ }^{125} \mathrm{I}$-NT binding sites could be shown on TH-IR cells (Fig. $5 A, B$ ). Grain accumulation was present on both cell bodies and processes. Cell counting revealed that, over a total number of $400 \pm 39 \mathrm{TH}-$ IR cells/well, $322 \pm 30$ TH-IR cells were labeled with ${ }^{125}$ I-NT (Table 1). In the mesencephalic cultures, $80 \%$ of the TH-IR cells thus expressed ${ }^{125} \mathrm{I}-\mathrm{NT}$ binding sites. The remaining $20 \%$ of TH-
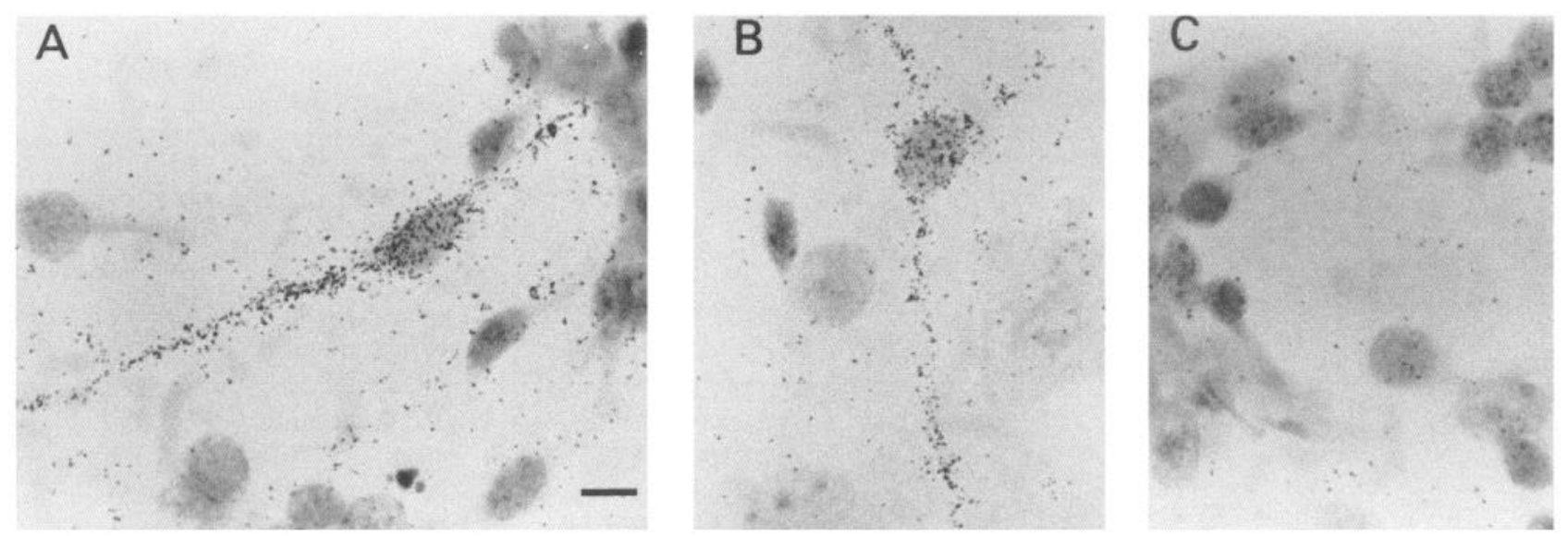

Figure 2. Radioautographs of ${ }^{125} \mathrm{I}-\mathrm{NT}$ total $(A, B)$ and nonspecific $(C)$ binding to rat mesencephalic cells in culture. Cells were counterstained with cresyl violet. Note the cell-like appearance of the silver grain accumulation in $A$ and $B$, and the lack of such an image in $C$. Scale bar, $10 \mu$ m. 

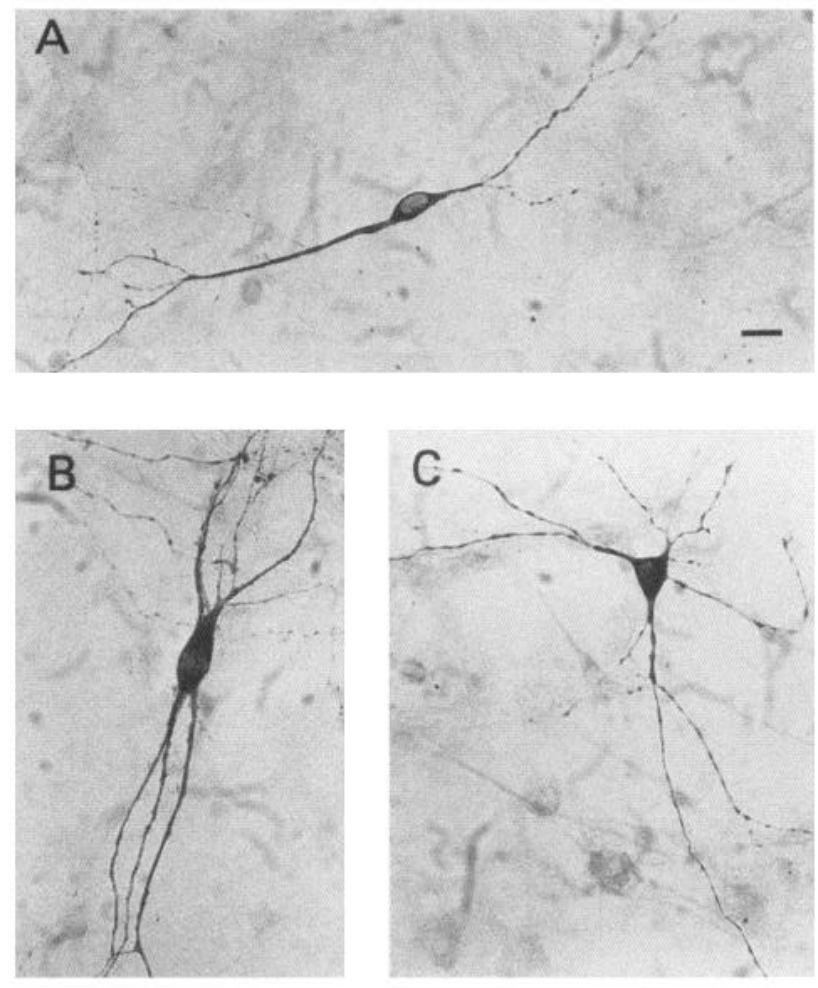

Figure 3. TH immunocytochemistry micrographs of mesencephalic cells in culture: bipolar $(A)$, multipolar $(B)$, and tripolar $(C)$ cells. Scale bar, $20 \mu \mathrm{m}$.

IR cells appeared to be devoid of silver grain accumulation (Fig. $5 C$ ). According to our previous experiments with single labeling in which the number of ${ }^{125} \mathrm{I}-\mathrm{NT}$-labeled cells exceeded that of TH-IR cells, ${ }^{125}$ I-NT sites were also detected on TH-negative cells (Fig. 5D). These cells represented $54 \%$ of the total number of cells ( $701 \pm 67$ cells/well) labeled by the radioligand (Table 1).

\section{Effect of $N T$ and related peptides on ${ }^{3} \mathrm{H}-\mathrm{DA}$ release from mesencephalic cultures}

The previous anatomical studies clearly demonstrated the presence of ${ }^{125} \mathrm{I}-\mathrm{NT}$ sites on TH-IR cells characterized as DAergic

Table 1. ${ }^{125 I-N T}$ radioautography combined with TH immunocytochemistry: quantitative analysis of double-labeling experiments

Cells/well

\begin{tabular}{lc}
\hline TH-IR cells \\
Total number & $400 \pm 39$ \\
Labeled by ${ }^{125}$ I-NT & $322 \pm 30 \dagger \dagger$ \\
Unlabeled by ${ }^{125}$ I-NT & $78 \pm 9+\dagger$ \\
125I-NT-labeled cells & \\
Total number & $701 \pm 67+\dagger$ \\
TH immunoreactive & $322 \pm 30^{* *}$ \\
TH negative & $379 \pm 37^{* *}$ \\
& \\
\hline Cells were plated at a density of $5 \times 10^{5}$ cells/well and taken after $9 \mathrm{~d}$ in culture. \\
All values are presented as mean \pm SEM, $n=8$ for each value. \\
†† Significantly different $(p<0.001)$ from total number of TH-IR cells (Student's \\
paired $t$ test). \\
** Significantly different $(p<0.001)$ from total number of ${ }^{125}$ I-NT-labeled cells \\
(Student's paired $t$ test).
\end{tabular}

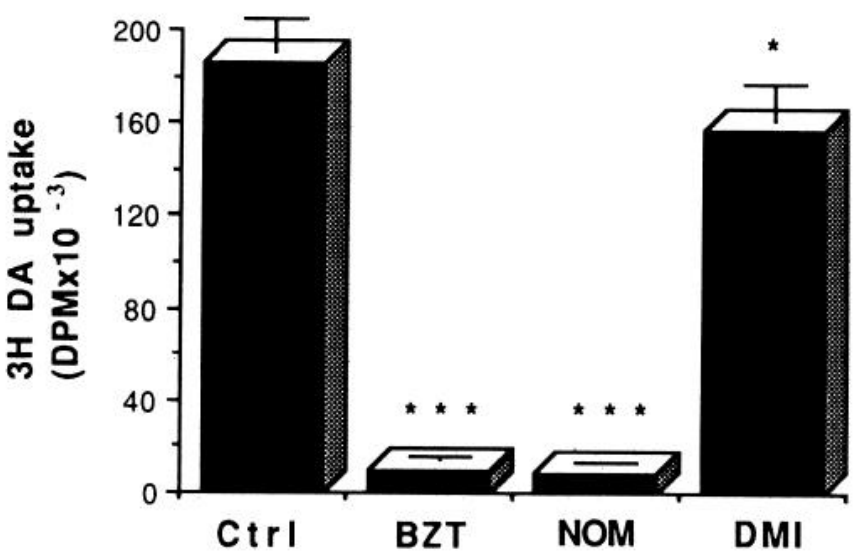

Figure 4. Sensitivity of ${ }^{3} \mathrm{H}-\mathrm{DA}$ uptake to monoamine uptake inhibitors. Cells were incubated with ${ }^{3} \mathrm{H}-\mathrm{DA}$ in the absence $(\mathrm{Ctrl})$ or in the presence of benztropine $(B Z T, 5 \mu \mathrm{M})$, nomifensine $(N O M, 5 \mu \mathrm{M})$, or desipramine $(D M I, 5 \mu \mathrm{M})$. Each value is the mean \pm SEM of four determinations. Statistical differences from the control group $(\mathrm{Ctr} l)$ were assessed using Dunnett's test. ${ }^{*}, p<0.05 ;{ }^{* * *}, p<0.001$.

neurons. In order to check whether these binding sites represented physiologically functional NT receptors, the effect of NT on DA release was tested. As shown in Figure 6, NT was able to increase potassium-evoked release of previously uptaken ${ }^{3} \mathrm{H}$ DA. The minimal effective concentration was $10^{-10} \mathrm{M}$, and the maximal effect was obtained at $10^{-7} \mathrm{M}$ NT. This maximal effect represented a $54 \%$ increase $(54.0 \pm 5.0 \%, p<0.01, n=22)$ of the potassium-induced DA release. $\mathrm{AcNT}_{8-13}\left(\mathrm{EC}_{50}=0.28 \mathrm{~nm}\right)$ was as potent as NT $\left(\mathrm{EC}_{50}=0.35 \mathrm{nM}\right)$, while $\mathrm{NT}_{1-11}$ was inactive up to $10^{-6} \mathrm{M}$ (Fig. 6). When the potency of several NT fragments or analogs to stimulate DA release was compared with their ability to displace ${ }^{125} \mathrm{I}-\mathrm{NT}$ binding in these cultures, a linear relationship ( $r=0.989)$ was found between the two sets of data (Fig. 7). No effect of NT or related peptides $\left(10^{-10}\right.$ to $\left.10^{-5} \mathrm{M}\right)$ on basal DA release could be observed under these conditions.

\section{Discussion}

We show in this article that rat embryonic DAergic neurons in primary cultures express functional NT receptors. This demonstration was achieved by the combination of (1) an original double-labeling protocol, combining both ${ }^{125} \mathrm{I}-\mathrm{NT}$ receptor radioautography and $\mathrm{TH}$ immunocytochemistry, which provided the first direct visualization of NT binding sites on TH-IR neurons; (2) the identification of the TH-IR neurons present in the mesencephalic cultures as DAergic neurons; and (3) pharmacological experiments showing the ability of NT and its analogs to increase potassium-evoked release of ${ }^{3} \mathrm{H}-\mathrm{DA}$.

We have shown previously that postfixation of ${ }^{125} \mathrm{I}-\mathrm{NT}$-labeled tissue sections with high concentrations of glutaraldehyde ensured irreversible cross-linking of the radioligand to, or nearby, its binding sites (Moyse et al., 1987). We thus applied this approach for the electron microscopic localization of ${ }^{125} \mathrm{I}-\mathrm{NT}$ binding sites in the rat mesencephalon (Dana et al., 1989). In the present work, we demonstrate that this procedure can be used on cells in culture to identify the cell populations expressing ${ }^{125}$ I-NT binding sites.

The technical difficulties encountered on tissue sections by others (Szigethy and Beaudet, 1989) to combine, in the same biological sample, NT receptor radioautography and TH immunocytochemistry were overcome in cultured cells. Indeed, 

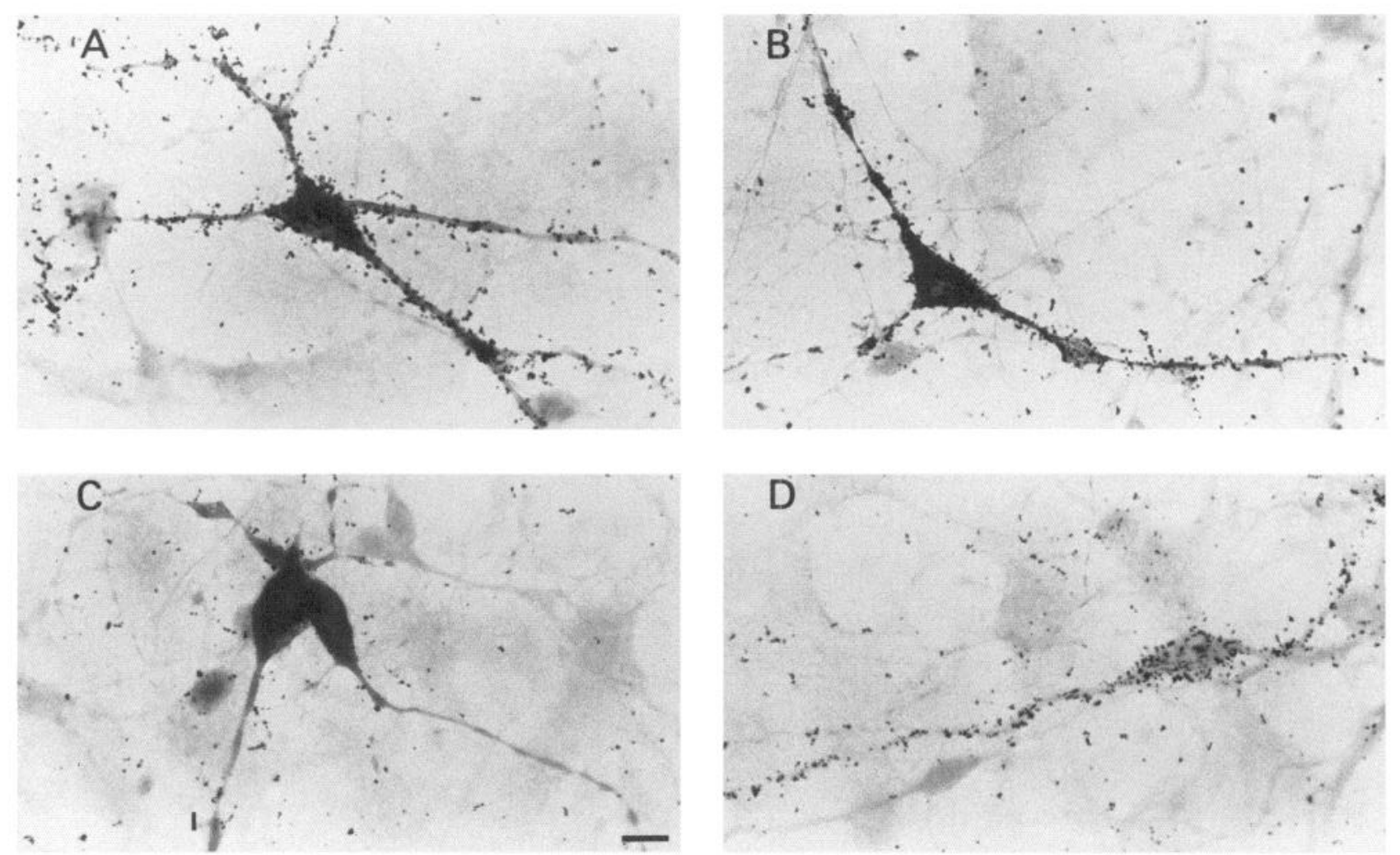

Figure 5. Double-labeling experiments associating both ${ }^{125} \mathrm{I}-\mathrm{NT}$ receptor radioautography and TH immunocytochemistry. Some TH-IR cells possessed silver grain accumulations $(A, B)$ indicating expression of NT binding sites by these cells, while some other TH-IR cells were devoid of silver grains $(C)$. On the other hand, NT binding sites could be observed in some TH-negative cells $(D)$. Scale bar, $10 \mu \mathrm{m}$.

TH antigenicity could be retained in spite of the various histological procedures needed for NT cross-linking onto its binding sites. The main reason for it, in our opinion, is that slicing unfixed or only lightly fixed brain, as needed to retain NT receptor binding on brain sections (Moyse et al., 1987; Dana et al., 1989; Szigethy and Beaudet, 1989), damages the tissue and

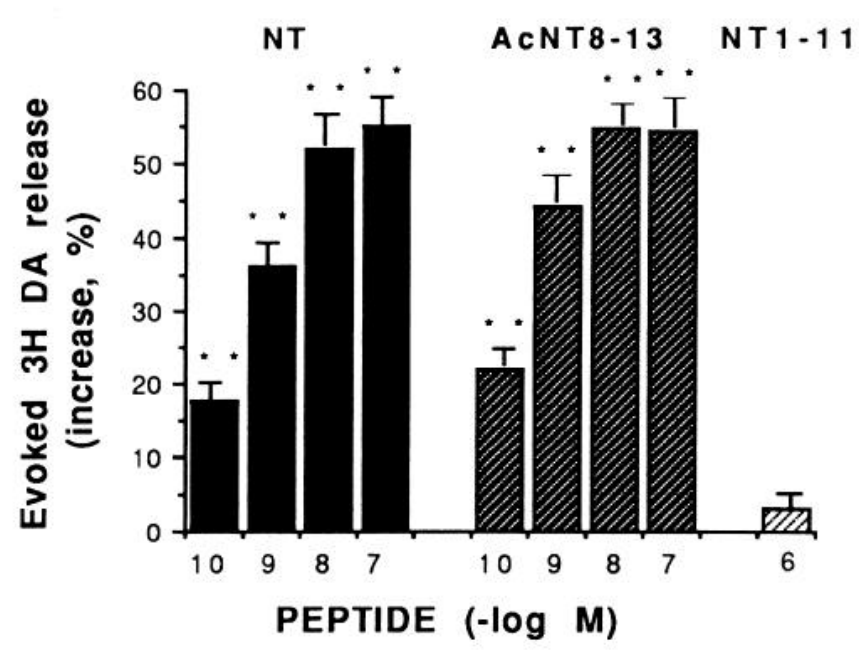

Figure 6. Effect of NT fragments on potassium-evoked ${ }^{3} \mathrm{H}-\mathrm{DA}$ release by rat mesencephalic cells in culture. Results are presented as percentage increase in ${ }^{3} \mathrm{H}-\mathrm{DA}$ release relative to control (release evoked by $20 \mathrm{~mm}$ $\mathrm{K}^{+}$without any NT-related peptide). Each value is the mean \pm SEM of four determinations, and statistical differences versus control were assessed using Dunnett's test. ${ }^{* *}, p<0.01$. $M$, peptide concentration. may favor the loss of intracellular antigens during the binding protocol. In the present case, the cells remained in a suitable medium until the fixation and no slicing step was required. These conditions may favor the maintenance of intracellular antigens.

In the rat mesencephalic cultures, $80 \%$ of the TH-IR cells

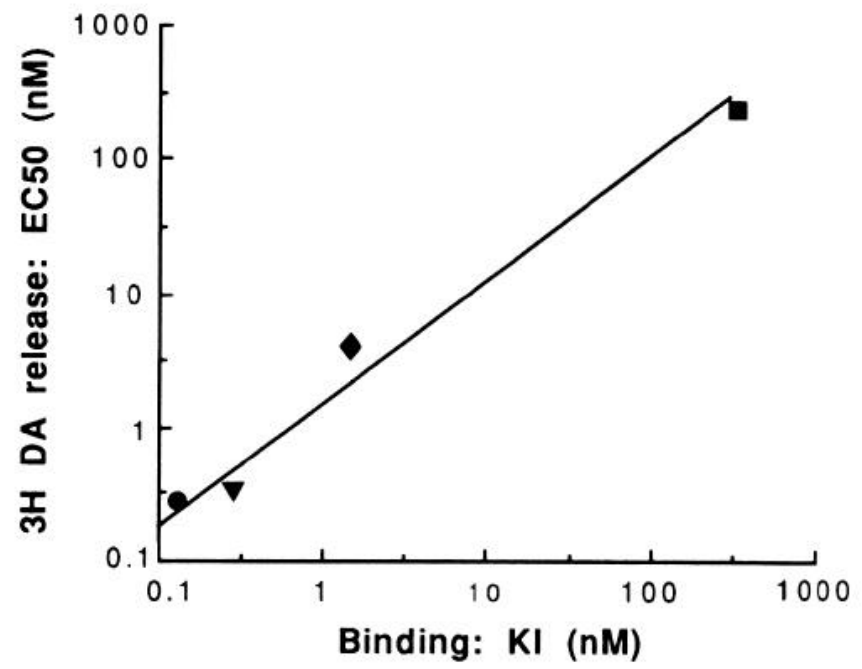

Figure 7. Correlation between the potencies of NT-related peptides to increase ${ }^{3} \mathrm{H}$-DA relcase and their abilities to compete with ${ }^{125} \mathrm{I}-\mathrm{NT}$ binding. $\mathrm{EC}_{50}$, peptide concentration producing half the maximal increase in ${ }^{3} \mathrm{H}$-DA release. $K I$, inhibitory constant found in binding experiments. Correlation coefficient $(r)$ was 0.989 . $\bullet$, AcNT $_{8-13} ; \boldsymbol{\nabla}$, NT; $\diamond$, neuromedin $\mathrm{N} ; \boldsymbol{\square}, \mathrm{NT}_{1-12}$. 
possessed ${ }^{125}$ I-NT sites. These TH-IR cells may be identified as DAergic neurons since they were able to take up ${ }^{3} \mathrm{H}$-DA in a benztropine- and nomifensine-sensitive manner (Prochiantz et al., 1979). The functional aspect of NT sites was attested by the ability of several NT-related peptides to increase the release of ${ }^{3} \mathrm{H}-\mathrm{DA}$ in this system and by the relationship found between the relative activities of these peptides and their affinities for the NT binding sites. Such an action of NT on the regulation of DA release has been observed in the adult brain (see Ervin and Nemeroff, 1989, and Faggin and Cubeddu, 1990, for references). Moreover, it should be noticed that the binding characteristics of these NT sites in cultured mesencephalic cells are similar to those previously obtained for the high-affinity NT sites in the adult rat brain (Granier et al., 1982; Sadoul et al., 1984; Kitabgi et al., 1987; Moyse et al., 1987). Taken together, these results clearly show that, even at this early developmental stage, NT binding sites detected on mesencephalic DAergic neurons are already under a mature form, and that binding of the ligand is coupled to a biological effect. These sites may therefore be considered as functional NT receptors. The presence of NT receptors on both cell bodies and processes suggests that the peptide may act at the level of these various elements of the DAergic neurons. We cannot, however, determine whether the NT-induced increase in DA release observed under our experimental conditions reflects an action of NT on dendrites, axon terminals, or both. It also remains possible that some of the binding sites visualized in this study represent sites in transport (Dana et al., 1989).

Interestingly, both the high percentage of DAcrgic ncurons expressing NT receptors and the cellular distribution of these receptors on cell bodies and processes, found in this work, are quite similar to results obtained in previous radioautographic studies performed on adult rat brain (Palacios and Kuhar, 1981; Quirion et al., 1985; Hervé et al., 1986; Szigethy and Beaudet, 1989). The presence of NT sites on both cell bodies and terminals of the DAergic neurons was indirectly suggested by the concomitant decreases of NT binding site densities observed after destruction of DAergic neurons by 6-hydroxydopamine, in mesencephalic regions such as SN or VTA and in DA projection areas such as striatum or nucleus accumbens (Palacios and Kuhar, 1981; Quirion et al., 1985; Hervé et al., 1986). Dendritic and perikaryal localizations of NT sites were also observed in SN and VTA by light microscopy (Moyse et al., 1987; Szigethy and Beaudet, 1989), and in VTA by means of electron microscopic detcrmination (Dana et al., 1989). The good correspondence between the results of the present study and those obtained in the adult rat brain suggests that mesencephalic DA neurons in culture do not substantially differ from DA cells "in situ" in their ability to express NT receptors. Although obtained on primary cultures of embryonic cells, our data might thus also be considered to provide an anatomical support for the various effects of NT, observed in adult brain, on the different elements of DA neurons, that is, excitation of SN and VTA neurons (Pinnock, 1985; Seutin et al., 1989), alteration of dendritic nigral DA release (Myers and Lee, 1983) and of DA release in striatum or nucleus accumbens (De Quidt and Emson, 1983; Hétier et al., 1988; Blaha et al., 1990), as well as behavioral responses following intra-VTA injections (Kalivas et al., 1983; Cador et al., 1985).

Finally, a small percentage $(20 \%)$ of TH-IR neurons were unlabeled by ${ }^{125}$ I-NT. As there is no way to distinguish between mesolimbic, mesocortical, and nigrostriatal DA neurons in these cultures, we cannot conclude that DA neurons devoid of NT sites belong to one or another DAergic population. This percentage of unlabeled TH-IR neurons appears, however, to be quite similar to that of DA neurons exhibiting NT immunoreactivity in the adult rat brain (Hökfelt et al., 1984). It would thus be of interest to know whether these unlabeled TH-IR neurons represent colocalized DA-NT neurons. Similarly, further studies will be necessary to characterize the phenotype of the TH-negative cells that were labeled with ${ }^{125} \mathrm{I}-\mathrm{NT}$ in the mesencephalic cultures, and to elucidate the functional significance of this observation.

In conclusion, the present study clearly shows that mesencephalic DAergic neurons at early stages of development express functional NT receptors distributed both on cell bodies and processes of the neurons. These data thus enlighten the anatomical bases governing the regulation of the DAergic transmission by NT at the level of the DAergic neuron itself. Moreover, the original double-labeling approach developed in this study is applicable to other brain regions, other peptide receptors, and various types of cells, allowing the precise determination of the cells expressing a given receptor. Due to the complexity of the brain circuitry, this kind of approach could improve our understanding of the interactions between neuromediators and the physiological meaning of these interactions in brain functions or pathology.

\section{References}

Arluison M, Dielt M, Thibaud J (1984) Ultrastructural morphology of dopaminergic nerve terminals and synapses in the striatum of the rat using tyrosine hydroxylase immunocytochemistry. Topographical study. Brain Res Bull 13:269-285.

Barbin G, Mallat M, Prochiantz A (1985) In vitro studies on the maturation of mesencephalic dopaminergic neurons. Dev Neurosci 7:296-307.

Berger B, Di Porzio U, Daguet MC, Gay M, Vigny A, Glowinski J, Prochiantz A (1982) Long-term development of mesencephalic dopaminergic neurons of mouse embryos in dissociated primary culture: morphological and histochemical characteristics. Neuroscience 7:193205.

Blaha CD, Coury A, Fibiger HC, Phillips AG (1990) Effects of neurotensin on dopamine release and metabolism in the rat striatum and nucleus accumbens: cross-validation using in vivo voltammetry and microdialysis. Neuroscience 34:699-705.

Bockaert J, Gabrion J, Sladeczek F, Pin JP, Recasens M, Sebben M, Kemp D, Dumuis A, Weiss S (1986) Primary culture of striatal neurons: a model of choice for pharmacological and biochemical studies of neurotransmitter receptors. J Physiol (Paris) 81:219-227.

Cador M, Kelley AE, Le Moal M, Stinus L (1985) Behavioral analysis of the effect of neurotensin injection into the ventral mesencephalon on investigatory and spontaneous motor behavior in the rat. Psychopharmacology 85:187-196.

Carraway RE, Leeman SE (1973) The isolation of a new hypotensive peptide, neurotensin from bovine hypothalami. J Biol Chem 248: 6854-6861.

Chabry J, Checler F, Vincent JP, Mazella J (1990) Colocalization of neurotensin receptors and of the neurotensin-degrading enzyme endopeptidase 24-16 in primary cultures of neurons. J Neurosci 10: 3916-3921.

Checler F, Mazella J, Kitabgi P, Vincent JP (1986) High-affinity receptor sites and rapid proteolytic inactivation of neurotensin in primary cultured neurons. J Neurochem 47:1742-1748.

Cheng YC, Prusoff WH (1973) Relationship between the inhibition constant $\left(K_{i}\right)$ and the concentration of inhibitor which causes 50 percent inhibition $\left(\mathrm{IC}_{50}\right)$ of an enzymatic reaction. Biochem Pharmacol 22:3099-3108.

Chinaglia G, Probst A, Palacios JM (1990) Neurotensin receptors in Parkinson's disease and progressive supranuclear palsy: an autoradiographic study in basal ganglia. Neuroscience 39:351-360.

Dal Toso R, Giorgi O, Soranzo C, Kirschner G, Ferrari G, Favaron M, 
Benvegnù D, Presti D, Vicini S, Toffano G, Azzone GF, Leon A (1988) Development and survival of dissociated fetal mesencephalic serum-free cell cultures. I. Effect of cell density and of an adult mammalian striatal-derived neurotrophic factor (SDNF). J Neurosci 8: 733-745.

Dana C, Vial M, Leonard K, Beauregard A, Kitabgi P, Vincent JP, Rostène W, Beaudet A (1989) Electron microscopic localization of neurotensin binding sites in the midbrain tegmentum of the rat. 1 . Ventral tegmental area and interfascicular nucleus. J Neurosci 9:22472257.

Dana C, Pelaprat D, Vial M, Brouard A, Lhiaubet AM, Rostène W (1991) Characterization of neurotensin binding sites on rat mesencephalic cells in primary culture. Dev Brain Res 61:259-264.

De Quidt M, Emson PC (1983) Neurotensin facilitates dopamine release in vitro from rat striatal slices. Brain Res 274:376-380.

Ehringer H, Hornykiewicz O (1960) Verteilung von adrenalin und dopamin (3-hydroxytryptamine) im Gehirn des Menschen im ihr Veerhalten bei Erkrankungen des Extrapyramidalen System. Wien Klin Wochenschr 38:1236-1239.

Engele J, Pilgrim C, Kirsch M, Reisert I (1989) Different developmental potentials of diencephalic and mesencephalic dopaminergic neurons in vitro. Brain Res 483:98-109.

Ervin GN, Nemeroff CB (1988) Interactions of neurotensin with dopamine-containing neurons in the central nervous system. Prog Neuropsychopharmacol \& Biol Psychiatry 12:S53-S69.

Faggin BM, Cubeddu LX (1990) Rapid desensitization of dopamine release induced by neurotensin and neurotensin fragments. J Pharmacol Exp Ther 253:812-818.

Granier C, Van Rietschoten J, Kitabgi P, Poustis C, Freychet P (1982) Synthesis and characterization of neurotensin analogues for structure/ activity relationship studies. Acetyl-neurotensin (8-13) is the shortest analogue with full binding and pharmacological activities. Eur J Biochem 124:117-125.

Greene LA, Rein G (1976) Synthesis, storage and release of acetylcholine by a noradrenergic pheochromocytoma cell line. Nature 268 : 349-351.

Hervé D, Tassin JP, Studler JM, Dana C, Kitabgi P, Vincent JP, Glowinski J, Rostène W (1986) Dopaminergic control of ${ }^{125}$ I-labeled neurotensin binding sites in corticolimbic structures of the rat brain. Proc Natl Acad Sci USA 83:6203-6207.

Hétier E, Boireau A, Dubedat P, Blanchard JC (1988) Neurotensin effects on evoked release of dopamine in slices from striatum, nucleus accumbens and prefrontal cortex in rat. Naunyn Schmiedebergs Arch Pharmacol 337:13-17.

Hökfelt T, Everitt BJ, Theodorsson-Norheim E, Goldstein M (1984) Occurrence of neurotensin-like immunoreactivity in subpopulations of hypothalamic, mesencephalic and medullary catecholaminergic neurons. J Comp Neurol 222:543-559.

Kalivas PW (1985) Interactions between neuropeptides and dopamine neurons in the ventromedial mesencephalon. Neurosci Behav Rev 9: 573-587.

Kalivas PW, Burgess SK, Nemeroff CB, Prange AJ Jr (1983) Behavioral and neurochemical effects of neurotensin microinjection into the ventral tegmental area. Neuroscience 8:495-505.

Kitabgi P, Rostène W, Dussaillant M, Schotte A, Laduron PM, Vincent JP (1987) Two populations of neurotensin binding sites in murine brain: discrimination by the antihistamine levocabastine reveals markedly different radioautographic distribution. Eur J Pharmacol 140:285-293.
Matthysse SW, Kety SS, eds (1975) Catecholamines and schizophrenia. Oxford: Pergamon.

Mount H, Welner S, Quirion R, Boksa P (1989) Glutamate stimulation of $\left[{ }^{3} \mathrm{H}\right]$ dopamine release from dissociated cell cultures of rat ventral mesencephalon. J Neurochem 52:1300-1310.

Moyse E, Rostène W, Vial M, Leonard K, Mazella J, Kitabgi P, Vincent JP, Beaudet A (1987) Distribution of neurotensin binding in rat brain: a light microscopic radioautographic study using monoiodo (125) $\mathrm{Tyr}^{3}$ neurotensin. Neuroscience 22:525-536.

Myers RD, Lee TF (1983) In vivo release of dopamine during perfusion of neurotensin in substantia nigra of the unrestrained rat. Peptides 4: 955-961.

Palacios JM, Kuhar MJ (1981) Neurotensin receptors are located on dopamine-containing neurons in rat midbrain. Nature 294:587-589.

Palacios JM, Pazos A, Dietl MM, Schlumpf M, Lichtensteiger W (1988) Ontogeny of brain neurotensin receptors studied by autoradiography. Neuroscience 25:307-317.

Pinnock RD (1985) Neurotensin depolarizes substantia nigra dopaminergic neurons. Brain Res 338:151-154.

Prochiantz A, Di Porzio U, Kato A, Berger B, Glowinski J (1979) In vitro maturation of mesencephalic dopaminergic neurons from mouse embryos is enhanced in presence of their striatal target cells. Proc Natl Acad Sci USA 76:5387-5391.

Quirion R, Chiueh CC, Everitt HD, Pert A (1985) Comparative localization of neurotensin receptors on nigrostriatal and mesolimbic dopaminergic terminals. Brain Res 327:385-389.

Rostène W, Dubois A, Zajac JM, Agid F, Kitabgi P, Roques BP (1988) Changes in opioid, neurotensin receptor density and neutral endopeptidase in Parkinson and Huntington brains. Soc Neurosci Abstr 14:353.

Sadoul JL, Checler F, Kitabgi P, Rostène W, Javoy-Agid F, Vincent JP (1984a) Loss of high affinity neurotensin receptors in substantia nigra from Parkinson's subjects. Biochem Biophys Res Commun 125:395404.

Sadoul JL, Mazella J, Amar S, Kitabgi P, Vincent JP (1984b) Preparation of neurotensin selectively iodinated on the tyrosine 3 residue. Biological activity and binding properties on mammalian neurotensin receptors. Biochem Biophys Res Commun 120:812-819.

Seutin V, Massotte L, Dresse A (1989) Electrophysiological effects of neurotensin on dopaminergic neurones of the ventral tegmental area of the rat in vitro. Neuropharmacology 28:949-954.

Szigethy E, Beaudet A (1989) Correspondence between high affinity ${ }^{125}$ I-neurotensin binding sites and dopaminergic neurons in the rat substantia nigra and ventral tegmental area. A combined radioautographic and immunohistochemical light microscopic study. J Comp Neurol 279:128-137.

Thomas EW (1986) Studies of neurotransmitter chemistry of central nervous system neurons in primary tissue culture. Life Sci 38:297308.

Uhl GR, Whitehouse PJ, Price DL, Tourtelotte WW, Kuhar MJ (1984) Parkinson's disease: depletion of substantia nigra neurotensin receptors. Brain Res 308:186-190.

Woulfe J, Beaudet A (1989) Immunocytochemical evidence for direct connections between neurotensin-containing axons and dopaminergic neurons in the rat ventral midbrain tegmentum. Brain Res 479:402406. 